\title{
Performance Enhancement of Small Capacity Gasoline Engine using Electric Supercharger-Review Study
}

\author{
Hardik K Patel ${ }^{1}$, Arvind Gothwal ${ }^{2}$ \\ Student, M.E IC/Auto, Merchant Institute of Technology, Piludara, Gujarat,India ${ }^{1}$ \\ Asst Prof, Mechanical Engineering Department, Merchant Institute of Technology, Piludara, Gujarat,India ${ }^{2}$
}

\begin{abstract}
The concept of exploiting the supercharging phenomenon has evolved with rather small steps, to obtain optimum performance by varying parameter to improve performance parameters of Internal Combustion Engine conceptualized for Two Wheeler. In addition to foregoing merits implementation of supercharger enhances the increment of Mechanical and Volumetric Efficiency at variable speed and load. Thereafter the various problems faced by two wheeler on higher altitude, air available is thin thereby deficiency of oxygen can led to low power output can be challenging criteria by means of Supercharging.
\end{abstract}

Keywords: Volumetric Efficiency, Deficiency of Oxygen, Supercharging, Performance Optimization.

\section{INTRODUCTION}

Superchargers increase intake by compressing air above atmospheric pressure, without creating a vacuum. This forces more air into the engine, providing a "boost." With the additional air in the boost, more fuel can be added to the charge, and the power of the engine is increased. In high-altitude situations, where engine performance deteriorates because the air has low density and pressure, a supercharger delivers higher-pressure air to the engine so it can operate optimally. To pressurize the air, a supercharger must spin rapidly -- more rapidly than the engine itself. Making the drive gear larger than the compressor gear causes the compressor to spin faster. Superchargers can spin at speeds as high as 50,000 to 65,000 rotations per minute (rpm).

Apart from increasing the volumetric efficiency of the engine supercharging results in increase in the intake temperature of the engine. Increased intake pressure and temperature reduces ignition delay and increase flame speed. Both these affect result in a greater tendency to detonate or pre-ignite. For this reason, the supercharged petrol engines employ lower compression ratio. The use of lower compression ratio and increase heat losses due to higher value of specific heats and dissociation losses at higher temperature results in lower thermal efficiency for such engines. Thus supercharged petrol engine have a greater fuel consumption than naturally aspirated Engines

\section{STUDY OF LITERATURE PAPER'S}

Sen. et al (2015) [1] have inquired about that However, the degree to which swept volume can be reduced in any downsized application is combustion restricted. In case the combustion in high speed, small bore engines may be better understood or indeed upgraded to promote faster burning, the severity of end-gas knock could be minimized. In compression proportion and/or manifold absolute weight, resulting in expanded performance and efficiency. These results show that the supercharged engine execution was primarily dependent on the mechanical loss to drive the supercharger at low speed. In addition, at high speed, the supercharged engine performance was more influenced by the compression ratio than mechanical loss. Engine performance investigations utilizing the supercharger demonstrate that the yield and torque execution can be improved in comparison with the naturally suctioned engine.

Pakale.P et al (2015)[2], has examined that Brake power will increase almost 30-45 percent since of increment in supercharged pressure as more sum of fuel will be burnt inside the same period as the mass taken per stroke is increased. The power-to-weight proportion, i.e. kilowatt (power output)/kilograms (engine weight); of the supercharged engine is much superior than that of the normally aspirated engine. The high height execution of a supercharged engine is essentially 


\section{International Advanced Research Journal in Science, Engineering and Technology}

Vol. 6, Issue 2, February 2019

superior. Since of reduced engine is smaller; it is in this manner less boisterous than a normally aspirated engine with indistinguishable output.

Murgovski.N.etal(2015)[3] has; done, a test consider ,they explored the situation of downsizing the engine, whereas conveyin $\mathrm{g}$ high power demands by supercharging. The supercharger, comprising of a compressor and an electric motor, draws electric power from a buffer. It given convex modelling steps that define the Problem as a moment arrange cone program that not only conveys the ideal engine and buffer Size, but too gives the ideal control and state trajectories for a given gear determination methodology. This paper gives arched modelling steps for the issue of ideally measuring the ICE and electric buffer (battery, or super capacitor), whereas conveying high power requests by supercharging.

Venkata.P et al(2015)[4], investigated that it is possible to install a supercharger for a commercial two wheelers which increases their horsepower on an average about $150 \%$ more than the original engine. So, supercharging can be an alternative for engines where more power and torque is desired on the verge of more fuel consumption.

Desai.S et al(2016)[5],researched that, Air is freely available in the atmosphere, thus supercharging would be a nonconventional solution for ameliorating the engine performance. Smaller engines equipped with supercharger can be used advantageously when excess power is required. After implementing supercharger, it has been seen that the performance of the vehicles improves in terms of power up to $10 \%$ to $15 \%$ and torque up to $5 \%$ to $10 \%$. It also improves mechanical efficiency and volumetric efficiency due to pressurized air is present in the cylinder. But there is some limitations to using of the supercharger because by using a supercharger increases specific fuel consumption as well as it increases knocking tendency.

Nayak H et al(2011)[6],has explored that, Boost is created at the point when the supercharger's inside impeller pushes sufficient air through the blower to overcome the vacuum force naturally made by the engine's air intake, so air is being constrained, instead of pulled, into the air intake. Boost is measured in Manifold Pressure, or Map. More boost compares to a more dense air charge into the engine's combustion chamber, which allows the engine to burn more air and fuel and make more drive. in this work the creator tries to extend the control and torque characteristics of the $125 \mathrm{cc}$ motor of the LML opportunity prepared with centrifugal compressor. The power created at $4000 \mathrm{rpm}$ is more than $3.3 \mathrm{KW}$ and increments as the rpm of the motor increases and gets to be maximum at $9000 \mathrm{rpm}$ about7.5 $\mathrm{KW}$. The torque of the engine begins from $7.9 \mathrm{Nm}$ at $4000 \mathrm{rpm}$ and gets to be most extreme approximately $9 \mathrm{Nm}$ at 7000 $\mathrm{rpm}$. Presently from figure 3.2 it can be seen that the valuable power developed at $4000 \mathrm{rpm}$ is more.

Pankaj B et al[7 ] has investigated that After implementation of Turbocharger in single cylinder petrol engine of Twowheeler, the BHP of the Engine increases \& BSFC increases at a certain loading conditions, but at high load BSFC decreases and RPM increases as compared without turbocharger. The emission of harmful exhaust gases will be in control while it passes through turbocharger. From observations it is conclude that percentage of $\mathrm{CO} \& \mathrm{CO} 2$ decreases \& also percentage of HC \& NOX decreases.

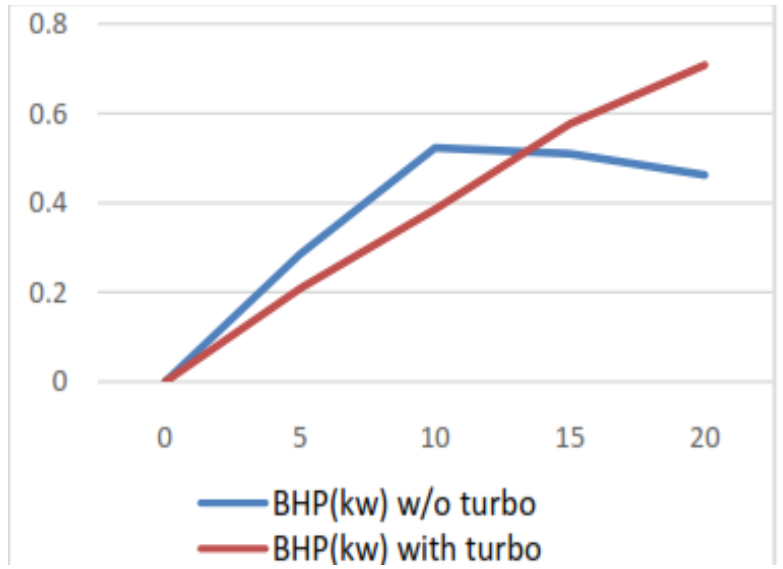

Fig:-1 Comparison of BHP v/s Load with and without turbo charging [7] 


\section{International Advanced Research Journal in Science, Engineering and Technology}

Vol. 6, Issue 2, February 2019

Akbari.K,et,al[8]has endorsed the change in performance of, IC engine by implementing supercharger. Inlet pressure is parameter that's focused upon because it will increment the compression proportion and in the long run the proficiency. The venture points to alter existing supercharger by utilizing adapt pinion arrangement between compressor and crankshaft to overcome power loss. Here from this writing we are able to see that the Control and torque characteristic of the engine, for both the condition of the vehicle with \& without a supercharger. It is seen that from the primary elucidation that the control created at $4000 \mathrm{rpm}$ is more than $3.3 \mathrm{KW}$ and increments as the rpm of the engine increments and gets to be greatest at $9000 \mathrm{rpm}$ almost $7.5 \mathrm{KW}$. The torque of the motor begins from $7.9 \mathrm{Nm}$ at $4000 \mathrm{rpm}$ and gets to be most extreme around $9 \mathrm{Nm}$ at $7000 \mathrm{rpm}$. Presently from the moment elucidation, it can be seen that the valuable control created at $4000 \mathrm{rpm}$ is more than $300 \mathrm{KW}$ which is much more than the control created without a supercharger.

\section{III.CONCLUSION}

An increment in the supercharging pressure increments the stack. Bearing areas and heavier components are required. These increments the frictional strengths. However, the increment in temperature is much more than increment in frictional powers. Normal values are $11 \%$ and $7.5 \%$ increment in frictional powers for petrol and diesel motors as compared to $40 \%$ increment in temperature for $60 \%$ supercharging. Hence the mechanical efficiency of supercharged engine is marginally better than the normally suctioned motor.

This increment in pressure and usually temperature also, because supercharging decreases start delay and consequently the motor includes,a knocking inclination .The knock limit is dependent upon,the sort offuel utilized, blend proportion, start development and the plan highlights of the engine, of which the valve the valve timing and cooling framework are important.

Power increase with increase in supercharged pressure as more amount of fuel will be burnt within the same period as the mass taken in per stroke is increased. By using some modification in naturally aspirated engine, supercharged application get influences in all field of internal combustion engine by obtain more power from given size of the engine. Limit of supercharging is imposed due to maximum permissible pressure and temperature and thermal stress in the cylinder.

\section{REFERENCES}

[1] Sen.P(2015) "An Integrative Literature review of Performance Analysis of Supercharging in S.I Engine and its Application" in International Journal of Advance Research In Science And Engineering comprising the journal number IJARSE, Vol. No.4, Special Issue (01), April 2015,ISSN-23198354(E).

[2] Pakale.P(2015) "Performance Analysis of Supercharging process in S.I Engine and C.I Engine and application of Supercharger" in International Journal of Advance Research In Science And Engineering comprising the journal number IJARSE, Vol. No.4, Special Issue (01), April 2015,ISSN2319-8354(E)

[3] Nikolce Murgovski(2015) "Power train sizing of electrically Supercharged Internal Combustion Engine" in Science Direct FAC-Papers 48-15 (2015) 101-108.

[4] Pasala.V(2015) "Performance Analysis of Supercharging a Single Cylinder SI Engine" in International Journal of Scientific and Engineering Research,Vol-6,Issue-12 ISSN 2229-5518.

[5] Desai.S et al (2016) "Analysis of Superchargers Implemented In Automobiles" in International Conference on Multi disciplinary Research and Practice in Vol 1 of ISSN 2321-2705.

[6] Nayak H et al (2011) "Performance Analysis of Supercharging of Two Wheelers" in IJMET,ISSN 0976-6340(Print) Volume-2, Issue-2.

[7] Pankaj B(2017) "Performance Analysis of Single Cylinder Petrol Engine with Turbocharger 'in ICHME-2017 Vol-5, Issue-6.

[8] Akbari K(2016) "Performance Improvisation of Pulsar Engine Using Supercharger" in International Journal of Modern Trends in Engineering and Research ISSN(ONLINE) : 2349-9745 ISSN(PRINT) : 2393-8161. 